\title{
КЛІНІЧНИЙ ПЕРЕБІГ ПОЛОГІВ ТА ПУЕРПЕРАЛЬНОГО ПЕРІОДУ У ЖІНОК ІЗ ЕПШТЕЙНА-БАРР ВІРУСНОЮ ІНФЕКЦІЕЮ
}

ДВНЗ «Ужгородський національний університет»

\begin{abstract}
Резюме. В останні роки особливого значення набувають проблеми хронічних персистувальних інфекцій, однією 3 яких $є$ Епштейна-Барр вірусна інфекція (ЕБВІ). Проведений аналіз перебігу пологів у жінок із ЕБВІ свідчить про достовірно високий рівень ускладнень при розродженні: передчасний розрив плодових оболонок (49,3\%), передчасні пологи (47,8 \%), аномалії пологової діяльності (7,0 \%), дистрес плода (16,9 \%) та акушерські кровотечі $(5,6 \%)$, що зумовлює високу
\end{abstract}

Вступ. Актуальність дослідження Епштейна-Барр вірусної інфекції викликана широкою циркуляцією цього вірусу серед населення, різноманіттям іiї клінічних форм, специфічною тропністю вірусу до імунокомпетентних клітин $[4,5,7]$.

За даними ВОО3, вірусом Епштейна-Барр (ВЕБ) інфіковано близько 55-60 \% дітей раннього віку (до трьох років), переважна більшість дорослого населення (90-98 \%) мають антитіла до ВЕБ. Захворюваність у різних країнах світу коливається від 40 до 80 випадків на 100 тис. населення і $€$ досить високим показником. Епштейна-Барр вірусна інфекція відноситься до групи некерованих інфекцій, за яких немає специфічної профілактики (вакцинації), що, безумовно, впливає на рівень захворюваності $[1,4,6,7,8]$.

ВЕБ $\epsilon$ представником онкогенних ДНКвірусів. Встановлено його роль у розвитку онкологічних захворювань і паранеопластичних процесів - лімфоми Беркітта, назофарингеальної карциноми, лімфогранулематозу (хвороби Ходжкіна), пухлин шлунка, кишечнику, слинних залоз, матки, волосатої лейкоплакії язика і слизової ротової порожнини, а також різноманітних автоімунних захворювань - системного червоного вовчаку, ревматоїдного артриту, синдрому Шегрена, лімфоїдного інтерстиціального пневмоніту, хронічного гепатиту, увеїту та інших. Поряд з вірусами герпесу людини 6-го і 7-го типів, ВЕБ $є$ етіологічним фактором синдрому хронічної втоми i найбільш частою причиною (15\%) розвитку тривалої лихоманки неясного генезу $[1,3,5,8]$.

Основний шлях передачі - повітрянокраплинний, можливі також контактнопобутовий і парентеральний. Існують дані про виділення ВЕБ із цервікального секрету, сперми і про можливість статевого шляху передачі вірусу. Описані випадки вертикальної передачі ВЕБ плоду, що можуть бути причиною внутрішньоутробних аномалій та призводять до ураження серця, очей та печінки плода. Припускають наявність інтранатального інфікування при проходжені плода через пологові шляхи. Він може міститися і в грудному молоці, однак такий шлях передачі залишається маловивченим $[1,2,4,5,6]$.

() А.Ю. Пекарь, Р.М. Міцода, 2016

116 частоту абдомінального розродження (30,9 \%) у цих вагітних. Аналізуючи перебіг пуерперального періоду, слід відзначити підвищений рівень порушень контрактильної активності матки $(25,4$ \%), ранової інфекції $(14,1 \%)$, післяпологового ендометриту $(8,4 \%)$, гіпогалактії $(38,0 \%)$ та анемії $(63,4 \%)$.

Ключові слова: вагітність, пологи, ЕпштейнаБарр вірусна інфекція, ускладнення.

Неухильне зростання рівня інфікування, переважання атипових форм перебігу, високий ризик канцерогенезу обгрунтовують необхідність ретельної діагностики та вивчення особливостей перебігу інфекції, викликаної ВЕБ, особливо у вагітних $[1,3,5]$.

Мета дослідження. Дослідити особливості перебігу пологів та пуерперального періоду в жінок із Епштейна-Барр вірусною інфекцією.

Матеріал і методи. Для досягнення поставленої мети проведено комплексне клінічнолабораторне обстеження 250 вагітних на ВЕБ, розроджених в Ужгородському міському пологовому будинку протягом 2014 - 2015 років. Рівень інфікування ВЕБ визначався 3 допомогою сучасних методів імуноферментного аналізу (ІФА) та полімеразно-ланцюгової реакції (ПЛР). Досліджувалися наявність антитіл IgM i IgG до капсидного, нуклеарного та ранніх антигенів ВЕБ (VCA, EBNA, EA VEB), авідність антитіл IgG до капсидного антигену ВЕБ (VCAVEB) та ДНК ВЕБ (DNAVEB) у крові вагітних. Визначення сироваткових маркерів проводилися на базі клінічної лабораторії Закарпатського обласного центру профілактики та боротьби зі СНІДом із використанням тест-систем: «Вектор-Бест» (Новосибірськ, РФ), «Euroimmun AG» (Німеччина), «Bio-Rad» (США), «АмплиСенс» (РФ).

Результати досліджень оброблено за допомогою пакета прикладних програм «Statistica». Для оцінки достовірності (p) різниці між групами показників використовувався t-критерій Стьюдента. У науковій роботі був прийнятий рівень достовірності $\mathrm{p}<0.05$.

Результати дослідження та їх обговорення. Найчастішими скаргами вагітних при надходженні до пологового будинку були перейми - 48 (45,3 \%), підтікання світлих н/п вод - 31 (29,2 \%), підвищення АТ від 140/100 до 170/110 мм рт.ст. $16(15,1 \%)$, ниючі болі внизу живота - 15 (14,2 \%). Рідше відмічалися набряки нижніх кінцівок, рук та обличчя - 7 (6,6\%), потуги - 4 $(3,7 \%)$, кров'янисті мажучі виділення - 4 (3,7\%), головний біль - 3 (2,8 \%), нудота та блювання - 3 (2,8 \%), болі у поперековій ділянці - 2 (1,8 \%), 
Клінічний перебіг пологів (абс.ч., \%)

\begin{tabular}{|c|c|c|}
\hline \multirow{2}{*}{ Показник } & \multicolumn{2}{|c|}{ Групи жінок } \\
\cline { 2 - 3 } & $\mathrm{K} \Gamma(\mathrm{n}=35)$ & $\mathrm{I}$ група $(\mathrm{n}=71)$ \\
\hline ПРПО & $3(8,6)$ & $35(49,3)^{*}$ \\
\hline Аномалії пологової діяльності & $1(2,8)$ & $4(5,6)^{*}$ \\
\hline Дистрес плода & $1(2,8)$ & $12(16,9)^{*}$ \\
\hline Акушерські кровотечі & $1(2,8)$ & $4(5,6)^{*}$ \\
\hline Передчасні пологи & $2(5,7)$ & $34(47,8)^{*}$ \\
\hline Кесарів розтин & $1(2,8)$ & $22(30,9)^{*}$ \\
\hline
\end{tabular}

Примітка. * - різниця достовірна порівняно з показниками КГ (p<0,05)

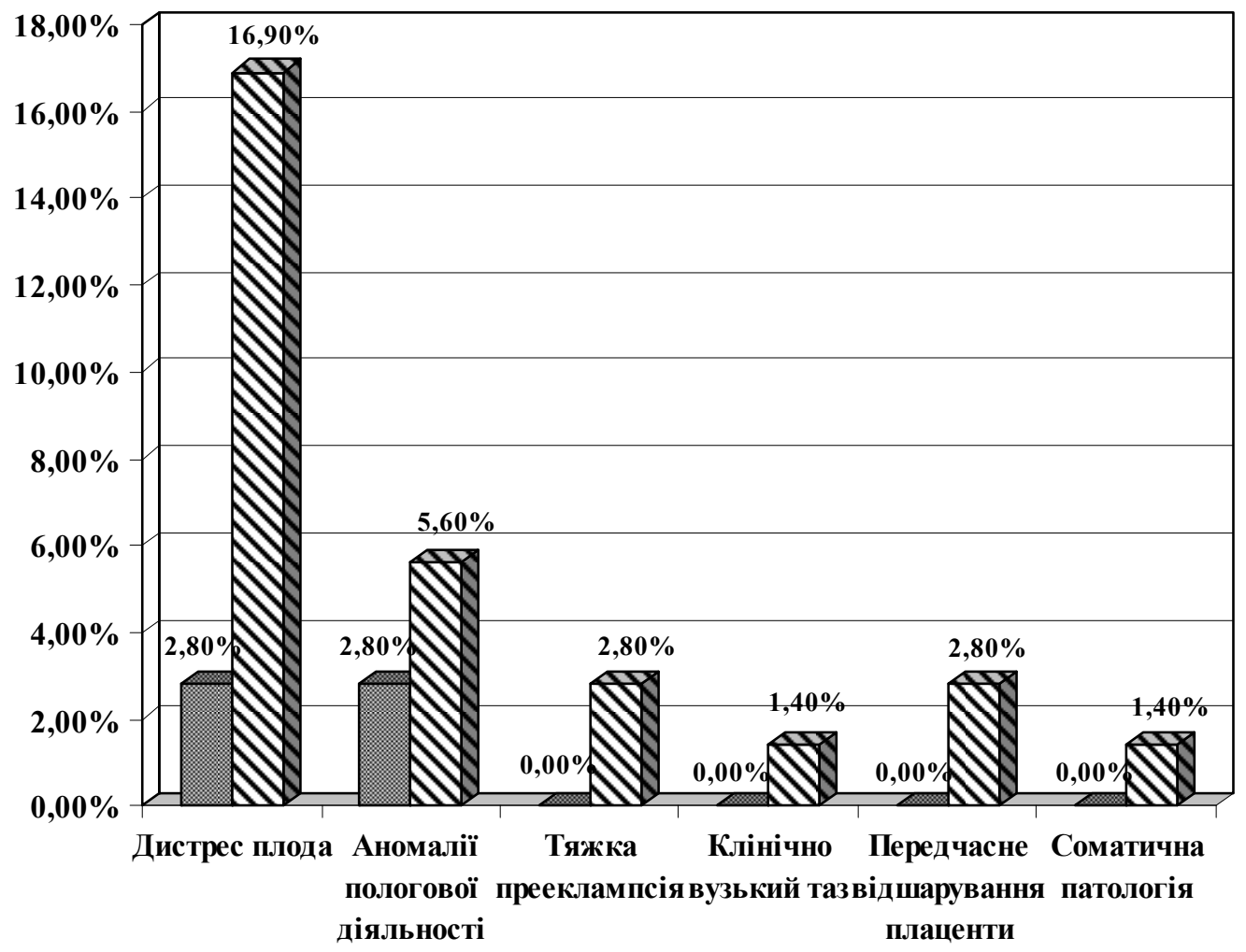

\begin{tabular}{|l|l|}
\hline $\mathbf{Q} \Gamma \mathrm{I}$ \\
\hline
\end{tabular}

Рис. 1. Покази до кесаревого розтину у вагітних I групи (n=22; 30,9 \%)

загальна слабкість - 2 (1,8 \%), а також втрата маси тіла, підвищення температури тіла до 39,8-40 ${ }^{\circ} \mathrm{C}$, задишка, затруднене дихання, носова кровотеча, зменшення рухової активності плода, прискорення рухової активності плода, дуже слабкі рухи плода по одному випадку відповідно (0,9\%). Скарги при надходженні не надавали $22(20,7 \%)$ жінки.

Згідно $з$ даними лабораторних обстежень, рівень інфікування вагітних ВЕБ становив 100\%, про що свідчать виявлені антитіла до ВЕБ у сироватці крові в усіх вагітних. Кожна третя жінка переносила активну ЕБВІ: 5 (2,0 \%) вагітних гостру первинну, 71 (28,4 \%) вагітна - реактивацію хронічної персистувальної інфекції. У 35 $(14,0$ \%) жінок мала місце латентна ЕБВІ. Більше ніж у половини обстежених - 137 (54,8 \%) спостерігалася хронічна неактивна ЕБВІ. У периферичній крові у 2 (0,8 \%) вагітних виявлено ДНК ВЕБ.

Проведено порівняльний клінічно-статистичний аналіз результатів пологів і післяпологового періоду в 71 вагітної із реактивацією ЕБВІ, що становили основну групу (І група) та 35 вагітних із латентною ЕБВІ, без акушерської і соматичної патології, які становили контрольну групу (КГ). Вагітних із гострою первинною та хронічною неактивною ЕБВІ навмисно виключено із подальшого етапу досліження.

Середній вік жінок основної групи склав $27,4 \pm 1,3$ року, контрольної - 23,5 $\pm 1,6$ року $(\mathrm{p}<0,05)$. У І групі кількість першовагітних скла- 


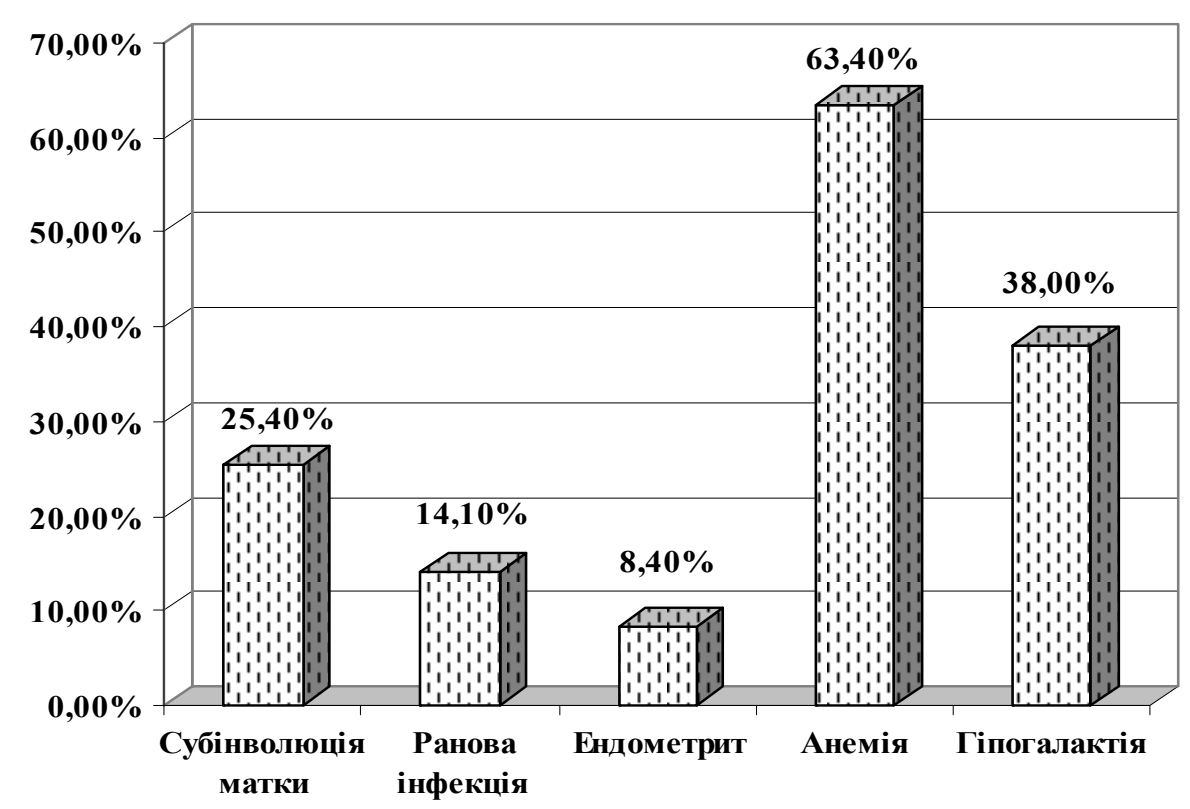

Рис. 2. Перебіг пуерперального періоду у досліджуваних жінок I групи (\%)

ла 28 (39,4 \%), повторновагітних - 43 (60,6 \%), у КГ першовагітних було 26 (74,3\%), повторновагітних $-9(25,7 \%) ; \mathrm{p}<0,05$.

Результати проведених досліджень вказують на високий рівень різноманітних ускладнень при розродженні (табл.), причому всі ці ускладнення $\epsilon$ взаємозалежними: передчасний розрив плодових оболонок (ПРПО) $(49,3 \%$; $<0,05)$, аномалії пологової діяльності $(7,0 \%)$, дистрес плода (16,9 \%) та акушерські кровотечі (5,6 \%).

Серед оперативних втручань у КГ був один випадок операції кесаревого розтину $(2,8 \%)$. У порівнянні $з$ цим, у вагітних I групи в пологах відзначений високий рівень кесаревих розтинів 22 випадки $(30,9 \%$; $<0,05)$. У структурі показів до кесаревого розтину (рис. 1) також були наявні певні розбіжності між групами. Якщо в КГ по одному випадку траплялися прогресуючий дистрес плода (2,8 \%) та аномалії пологової діяльності (2,8 \%) відповідно, то у вагітних I групи приводом до оперативного втручання шляхом кесаревого розтину стали: прогресуючий дистрес плода на тлі хронічної плацентарної дисфункції (ХПД) у 12 $(16,9$ \%) випадках, аномалії пологової діяльності у 4 (5,6 \%) випадках, тяжка прееклампсія у 2 (5,7 \%) випадках, передчасне відшарування нормально розміщеної плаценти у 2 (5,7 \%) випадках, соматичні захворювання та клінічно вузький таз по одному випадку (2,8 \%) відповідно.

Аналізуючи перебіг пуерперального періоду (рис. 2), слід відзначити підвищений рівень порушень контрактильної активності матки (25,4 \%), ранової інфекції $(14,1 \%)$, післяпологового ендометриту (8,4 \%), гіпогалактії (38,0 \%) та анемії $(63,4 \%)$, що відповідає клінічним особливостям перебігу пологів у вагітних із наявністю ЕБВІ.

\section{Висновок}

Проведений клінічно-статистичний аналіз дозволив дійти висновку, що пологи та пуерпера- льний період у жінок із Епштейна-Барр вірусною інфекцією проходять із достовірно високою частотою акушерських та післяпологових ускладнень.

Перспективи подальших досліджень. Вивчення функціонального стану фетоплацентарного комплексу та стану новонароджених від матерів із Епштейна-Барр вірусною інфекцією дозволить розробити методику прогнозування ризику акушерських і перинатальних ускладнень та лікувально-профілактичний алгоритм.

\section{Література}

1. Беременность и инфекция, вызванная вирусом Епштейна-Барр / Т.Н. Савченко, В.А. Алешкин, М.И. Агаева [и др.] // Рос. вестн. акуш.-гинекол. - 2014. - Т. 14, № 5. - С. 22-27.

2. Епштейна-Барр вирусная инфекция в перинатологии / В.Б. Котлова, С.П. Кокорева, Е.В. Аралова [и др.] // Здоровье и образование в XXI веке. - 2013. - Т. 15, № $8 .-$ C. $1-7$.

3. Эпштейна-Барр вирусная инфекция у детей: современные подходы к диагностике и лечению / Э.Н. Симованьян, В.Б. Денисенко, Л.Ф. Бовтало [и др.] // Леч. врач. - 2007. - № 7. - С. 36-41.

4. Клінічні форми хронічної Епштейна-Барр вірусної інфекції: питання сучасної діагностики та лікування / О.К. Дуда, Р.О Колесник, М.В. Окружнов [та ін.] // Актуал. инфектол. - 2015. - № 1 (6). - С. 35-40.

5. Крамарев С.А. Эпштейна-Барр вирусная инфекция у детей / С.А. Крамарев, О.В. Выговская // Актуал. инфектол. - 2013. - № 1 (1). - С. 73-78.

6. Осипова Л.С. Инфекция, вызванная вирусом Эпштейна-Барр / Л.С. Осипова // Клін. імунол., алергол., інфектол. - 2011. - № 9-10. - С. 28-35.

7. Покровська Т.В. Сучасні підходи до діагностики i клініки гострої Епштейна-Барр вірусної інфекції / Т.В. Покровська // Профілакт. мед. - 2013. - № 3-4 (21). - C. 50-55.

8. Шестакова И.В. Эпштейна-Барр вирусная инфекция у взрослых: вопросы патогенеза, клиники и диагностики / И.В. Шестакова, Н.Д. Ющук // Леч. врач. - 2010. № 10. - С. 40-44. 


\section{КЛИНИЧЕСКОЕ ТЕЧЕНИЕ РОДОВ И ПУЭРПЕРАЛЬНОГО ПЕРИОДА У ЖЕНЩИН С ЭПШТЕЙНА-БАРР ВИРУСНОЙ ИНФЕКЦИЕЙ}

\section{А.Ю. Пекарь, Р.М. Мицода}

Резюме. В последние годы особое значение приобретают проблемы хронических персистирующих инфекций, одной из которых является Эпштейна-Барр вирусная инфекция (ЭБВИ). Проведенный анализ течения родов у женщин с ЭБВИ свидетельствует о достоверно высоком уровне осложнений при родоразрешении: преждевременный разрыв плодных оболочек (49,3\%), преждевременные роды (47,8 \%), аномалии родовой деятельности $(7,0 \%)$, дистресс плода $(16,9 \%)$ и акушерские кровотечения $(5,6 \%)$, что обусловливает высокую частоту абдоминального родоразрешения $(30,9 \%)$ в этих беременных. Анализируя течение пуэрперального периода, следует отметить повышенный уровень нарушений сократительной активности матки $(25,4 \%)$, раневой инфекции $(14,1 \%)$, послеродового эндометрита $(8,4 \%)$, гипогалактии $(38,0 \%)$ и анемии $(63,4 \%)$.

Ключевые слова: беременность, роды, Эпштейна-Барр вирусная инфекция, осложнения.

\section{CLINICAL COURSE OF CHILDBIRTH AND PUERPERAL PERIOD IN WOMEN WITH EPSTEIN-BARR VIRUS INFECTION}

\section{A.Y. Pekar, R.M. Mitsoda}

Abstract. Problems of persistent chronic infections, one of which is the Epstein-Barr virus infection (EBVI) has become more important recently. The analysis of the flow of labor in women with EBVI indicates significantly higher rate of complications during delivery, premature rupture of membranes $(49,3 \%)$, premature birth $(47,8 \%)$, abnormal labor and delivery $(7,0 \%)$, fetal distress $(16,9 \%)$ and obstetric hemorrhage $(5,6 \%)$, which leads to high incidence of abdominal delivery $(30,9 \%)$ of these pregnant women. Analyzing the course of puerperal period should note the increased level of activity of the uterus kontraktylnoyi disorders $(25,4 \%)$, wound infection $(14,1 \%)$, postpartum endometritis $(8,4 \%)$, hypogalactia $(38,0 \%)$ and anemia $(63,4 \%)$.

Key words: pregnancy, childbirth, Epstein-Barr virus infection, complications.

SHEE «National University» (Uzhhorod)

Рецензент - проф. О.М. Юзько

Buk. Med. Herald. - 2016. - Vol. 20, № 1 (77). - P. 116-119

Надійшла до редакції 22.12.2015 року

() А.Ю. Пекарь, Р.М. Міцода, 2016 